\title{
An experimental approach in studying the influence of mercury on a North Sea coastal plankton community
}

\author{
J. KUIPER \\ Centraal Laboratorium TNO; Delf, The Netherlands
}

\begin{abstract}
The development of North Sea coastal plankton communities in four simultaneously filled plastic bags was followed for one month. To obtain a concentration of $5 \mathrm{ppb}$ in the water phase a single dose of mercuric chloride was added to two of the bags. This addition had a close impact on the development of the phytoplankton, while that on the zooplankton and the decomposers was less clear. In the course of the experiment, methylation of the added mercury proceeded in the sediment in the bags. The "plastic bag method" seems to be a suitable tool in toxicological research.
\end{abstract}

\section{INTRODUCTION}

Interpretation of the results of traditional toxicological laboratory experiments with single species, in terms of environmental significance, is difficult. Long-term experiments with more complex systems are urgently needed (Ringelberg, 1973; Lacaze, 1974; Kersting, 1975). Experimentation in the field, using toxic agents, encounters a number of practical difficulties. One way of bridging the gap between laboratory and natural conditions is to conduct experiments in large plastic bags housing plankton communities, the bags being suspended in natural water (Strickland \& Terhune, 1961; Goldman, 1962; Schelske \& Stoermer, 1971, 1972; Horstmann, 1972; Brockmann et al., 1974; Parsons, 1974).

In 1975, we carried out, in the harbour of Den Helder (The Netherlands), three experiments with North Sea coastal plankton communities enclosed in plastic bags (contents approximately $1400 \mathrm{l} / \mathrm{bag}$ ). The aim was to determine the influence of low concentrations of a pollutant on the structure and function of a marine plankton system. In the first two experiments, the development of the plankton community in four simultaneously filled bags showed, during 4-6 weeks, very similar patterns (cf. Takahashi et al., 1975), indicating that the method could be applied in toxicological research.

The aim of the third experiment was to investigate the development of the plankton system, when subjected to a single dose of mercury. Only the results of this experiment are reported here. 


\section{MATERIAL AND METHODS}

Figure 1 shows the construction of the bag; it is derived from that used by Brockman et al. (1974). Detailed information on the construction and operation of the bags will be published elsewhere. The experiment started August 25, 1975, and lasted one month. On the second day of the experiment, a single dose of mercuric chloride was added to two of the four bags in order to obtain a concentration of $5 \mathrm{ppb} \mathrm{HgCl}_{2}$ in the waterphase. To achieve this concentration, about 1001 water had been pumped from each bag into a PVC container, in which it was rapidly mixed with $0.7 \mathrm{I}$ of a $10 \mathrm{ppm} \mathrm{HgCl}_{2}$ solution in water. Next, the mixture was at once pumped back into the bag through a perforated ring of PVC tubing (diameter $60 \mathrm{~cm}$ ) which was slowly lowered into the bag to ensure thorough mixing of the $\mathrm{HgCl}_{2}$ solution with the original content of the bag.

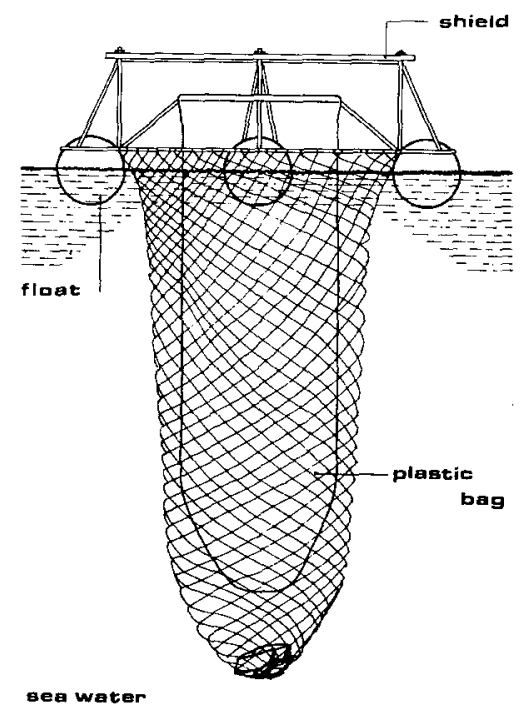

Fig. 1: Diagram of a plastic bag used for toxicological research

All samples, except those for zooplankton analysis, were collected daily at approximately 9 a. m., a non-metallic sampler being used at depths of 0.5 and $2.0 \mathrm{~m}$. Zooplankton samples were collected twice a week; the sampling technique then used had been applied before (Kuiper, in prep.).

The development of the phytoplankton was monitored by measuring chlorophyll a concentrations according to Strickland \& Parsons (1968) and by inspection of Lugolpreserved samples, using an inverted microscope (Lund et al., 1958; Utermöhl, 1958). Cell volumes were computed from cell measurements assuming simple geometric forms (Vollenweider, 1969). The pigment extract for chlorophyll analysis was also used to measure the pigment index (D430/D665) described by Margalef (1965). In his opinion, that index would be a measure for the diversity of the phytoplankton community. 
Primary production was measured by the ${ }^{14} \mathrm{C}$-method (Steemann-Nielsen, 1952); $100 \mathrm{ml}$ samples were added to $1 \mathrm{ml}$ of a $\mathrm{NaH}^{14} \mathrm{CO}_{3}$ solution ${ }^{*}$ in $125 \mathrm{ml}$ bottles. After $6 \mathrm{~h}$ of incubation in the bags (a set of one light and one dark bottle was used at a depth of $0.5 \mathrm{~m}$ and another such set at $2.0 \mathrm{~m}$ ), the bottles were transported to the laboratory in a dark box. Next, their contents were filtered through $0.45 \mu \mathrm{m}$ filters. Each filter was put in a scintillation solution (Anderson \& Zeutschel, 1970; Pugh, 1973) and the activity measured with a Nuclear Chicago Mark I liquid scintillation counter. Correction for quenching was made by the channels ratio method. Computations of the ${ }^{14} \mathrm{C}$ assimilation were corrected for ampoule activity and isotope discrimination.

The development of zooplankton was followed by counting the organisms in the samples; we used the same procedures as Fransz (1976). With respect to the copepods, the nauplius, copepodite and adult growth stages of the different species were identified; grow th and mortality rates were computed using the model of Fransz (1976).

The development of decomposers in the waterphase was followed by measuring the differences in ATP concentrations (according to the method of Holm-Hansen, 1969) on 0.45 and $3 \mu \mathrm{m}$ filters (Derenbach \& Williams, 1974).

Analyses of the concentrations of ortho-phosphate, nitrate, nitrite and reactive silicate were carried out as described by Strickland \& Parsons (1968). The mercury concentration in the waterphase was measured by atomic absorption spectrometry, with an IRDAB HGM 2300 spectrophotometer. The mercury adsorbed on the walls of the bags, and the mercury concentration of the sediment at the end of the experiment, were measured following Tjoe et al. (1973). Methylmercury concentrations in the sediment were determined according to Houpt and Compaan (1972) and Houpt (in preparation).

The Royal Dutch Meteorological Institute (KNMI) was so kind as to provide us with the integrated daily values of global radiation, measured at the meteorological station "De Kooy". Standard deviations were estimated from the measurements using analysis of variance. Time series in different bags were compared by means of regression analysis. The significance of differences between the coefficients of these regression lines was tested using Students $t$. Students $t$ was also used for testing the significance of differences between different measured values. Most statistical analyses were performed by the standard TSAM procedures of the Cyphernetics Information Corp. (CIC).

\section{RESULTS AND DISCUSSION}

\section{Development of phytoplankton}

The mercury concentrations measured in the morning of the third day of our experiment were the same as those calculated. Table 1 gives the mercury concentrations in the two bags, as a function of time.

Five days after the addition of mercury, the $\mathrm{Hg}$ concentration dropped below

* Ampoules with an activity of $3.8 \mu \mathrm{Ci} \mathrm{m}^{-1}$ had been provided by the International Agency for ${ }^{14} \mathrm{C}$ determination, Denmark. 
Table 1

Concentration of mercury in the waterphase (in $\mathrm{ppb}$ ). Averages of duplicate samples taken at 0.5 and $2.0 \mathrm{~m}$ respectively, and their standard deviations (s.d.)

\begin{tabular}{|c|c|c|}
\hline $\begin{array}{l}\text { Day of ex- } \\
\text { periment }\end{array}$ & $\begin{array}{c}\text { Bag } 1 \\
\mathrm{HgCl}_{2} \text { concentration }\end{array}$ & $\begin{array}{c}\text { Bag } 4 \\
\mathrm{HgCl}_{2} \text { concentration }\end{array}$ \\
\hline 0 & $<0.3$ & $<0.3$ \\
\hline 3 & $5.1 \pm 0.1$ & $5.2 \pm 0.1$ \\
\hline 4 & $1.7 \pm 0.4$ & $1.5 \pm 0.4$ \\
\hline 5 & $0.8 \pm 0.2$ & $1.0 \pm 0.2$ \\
\hline 6 & $0.7 \pm 0.3$ & $<0.3 \quad-$ \\
\hline $7-32$ & $<0.3 \pm-$ & $<0.3$ \\
\hline
\end{tabular}

Addition of the $\mathrm{HgCl}_{2}$ occurred on the 2 nd day of the experiment.

the detection limit $(0.3 \mathrm{ppb})$. As will be shown later, most of the mercury had probably been adsorbed by particles (cf. Smith et al., 1971) that settled on the bottom.

Figure 2 shows the development of chlorophyll $a$ in treated and untreated bags at a depth of $0.5 \mathrm{~m}$.

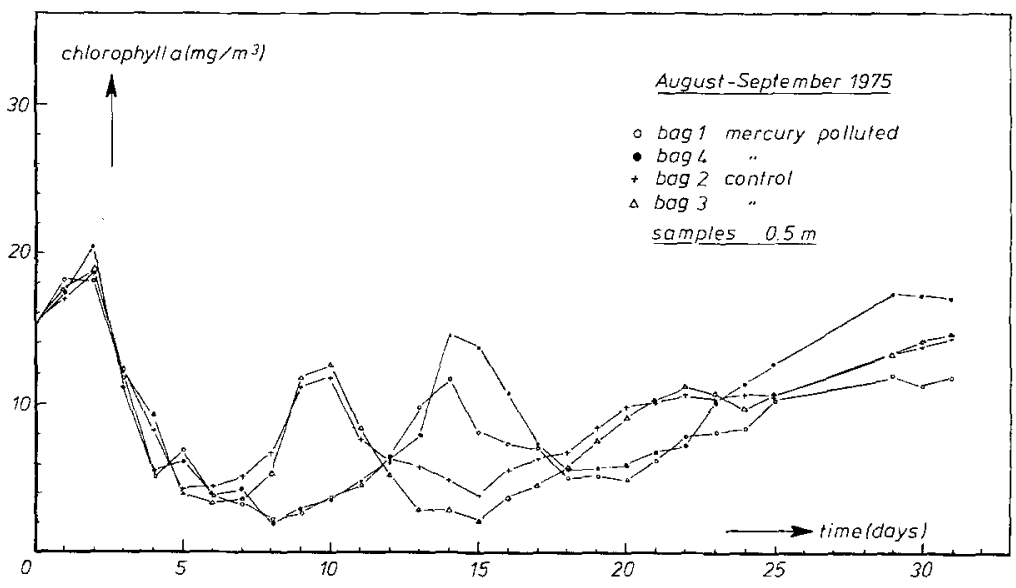

Fig. 2: Chlorophyll a concentration, at a depth of $0.5 \mathrm{~m}$ in mercury-polluted bags and non-polluted controls

Figure 3 gives the cell volume per liter of water for the dominant species in the phytoplankton. The water that was used to fill the bags contained a bloom of different diatom species from which Skeletonema costatum and Bacteriastrum byalinum continued growing in the bags, reaching a maximum on the second day, when mercury was added to the bags. Chlorophyll a concentrations in the polluted bags declined faster on the 3rd day of the experiment than in the unpolluted controls. On the fourth day, the chlorophyll concentration in the polluted bags increases, while that in the controls continues to decline. In the controls, a second bloom begins on the 6th day and reaches a maximum on the 10th day. This peak is mainly due to the colony- 
forming $\mu$-flagellate Phaeocystis pouchetii. In the polluted bags, the beginning of the second chlorophyll peak is delayed until the 9th day, reaching a maximum on the 14 th day. This peak is mainly due to free-living $\mu$-flagellates and, for a minor part, to $P$. pouchetii.

The second growth peak in the controls is followed by a minimum on the 15 th day, and there is a third maximum on the 21 st day. After this day, chlorophyll concentrations in the controls remain high. In the polluted bags, the second maximum is also followed by a less pronounced minimum and a new increase due to some species of $\mu$-flagellates.

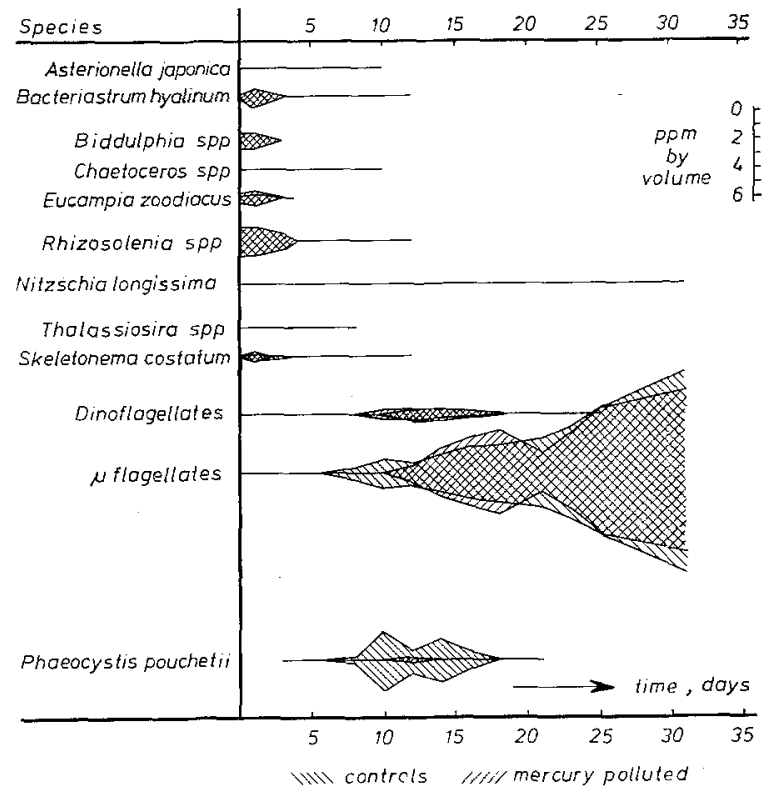

Fig. 3: Development of cell volume of main phytoplankton species in mercury-treated bags and controls

Compared to the standard deviation (s. d.) of the chlorophyll measurements itself (factor 1.08), the decline in chlorophyll concentrations on the $3 \mathrm{rd}$ day, and the increase on the 4 th day in the polluted bags, are significantly $(p<0.05)$ faster than in the controls. This means that, at concentrations higher than $1.5 \mathrm{ppb}$, mercury increases the rate of decline of the phytoplankton. In other words, mercury then reduces the growth rate of the phytoplankton. The small peak on the 5 th day is probably caused by growth of nutrients not yet used on the 3rd day. Clendenning (1958) found inhibition of the growth rate of Macrocystis pyrifera to occur at a concentration of $50 \mathrm{ppb} \mathrm{FigCl}$. For Scenedesmus sp. Bringmann \& Kuhn (1959) found growth rate inhibition at a concentration of $30 \mathrm{ppb}$. Ben Bassat et al. (1972) showed a lag of a few hours in the growth curve of Chlamydomonas reinbardii to be an effect of a concentration of $100 \mathrm{ppb}$ mercuric chloride. Nuzzi (1972) reports inhibition of growth rates of various phytoplankton species by $7 \mathrm{ppb} \mathrm{HgCl}_{2}$. The concentration of $1.5 \mathrm{ppb}$ 
that we found is also low compared with those occurring locally in polluted areas (Fonds, 1971; Smith et al., 1971; Kečkeš \& Miettinen, 1972).

A second effect of mercury addition is that, in the polluted bags, the second maximum is delayed four days, i. e. when $\mathrm{Hg}$ concentrations are no longer measurable. Ben Bassat et al. (1972) and Tompkins \& Blinn (1976) also found lag phases, as an effect of addition of $\mathrm{HgCl}_{2}$. Ben Bassat et al. (1972) suppose that the lag phase ends because the algae need time to convert the mercury, adsorbed by their cell walls, into a form which is not harmful to them. In our experiment, the possibility that mineralization is retarded in the mercury-polluted bags seems more likely.

A third effect of the mercury pollution is that the composition of the community of the second peak in the polluted bags differs from that in the controls. This is important because shifts in the community composition of the phytoplankton can have effects on higher trophic levels (Fisher \& Wurster, 1974).

Analysis of variance showed that, during the experiment, concentrations of chlorophyll at depths of 0.5 and $2.0 \mathrm{~m}$ did not differ significantly $(\mathrm{p}<0.05)$.

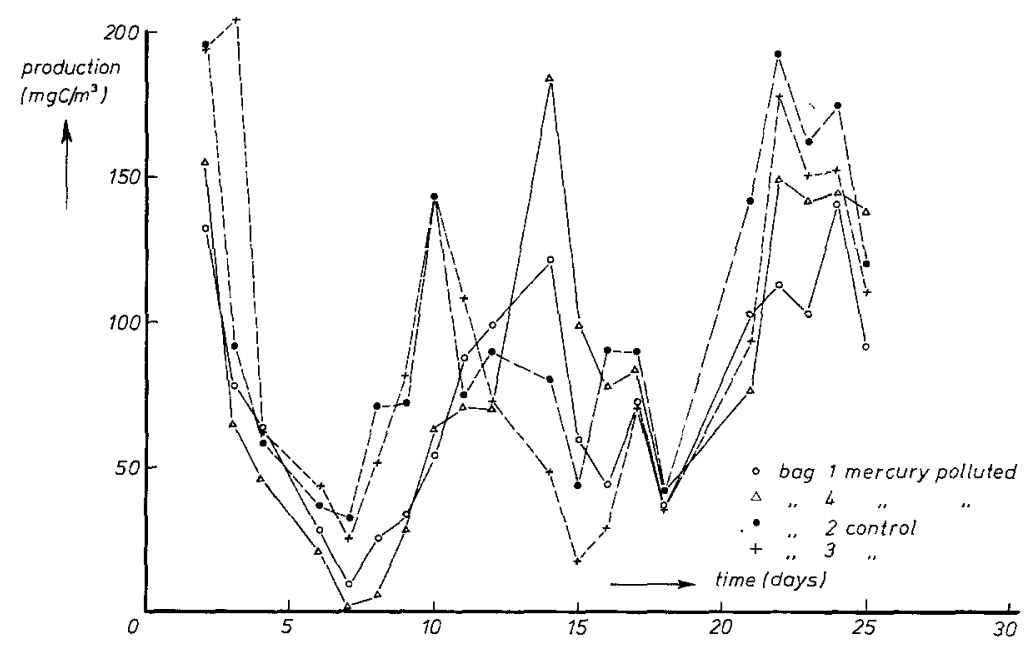

Fig. 4: Phytoplankton production (expressed as $\mathrm{mgC}$ production per $\mathrm{m}^{3}$ water) in different bags at a depth of $0.5 \mathrm{~m}$ from $9-15 \mathrm{~h}$

Figure 4 shows the phytoplankton production in the individual bags at the $0.5 \mathrm{~m}$ level. The pattern corresponds to that shown by the chlorophyll a concentrations (Fig. 2). The s. d. of the measurements is a factor of 1.28 and, therefore, too large to detect significant differences in the rate of decrease of the first peak between the polluted bags and the controls.

Contrary to results of the chlorophyll concentration, there is a marked effect of depth on the ${ }^{14} \mathrm{C}$-assimilation. Production at a depth of $0.5 \mathrm{~m}$ is almost always higher than at $2.0 \mathrm{~m}$. Cadée \& Hegeman (1974) state that the growth rate of wadden-sea phytoplankton is inhibited below light energy values of $0.84 \mathrm{~J} \mathrm{~cm}^{-2} \mathrm{~min}^{-1}$. Taking a 
day at 10 hours, inhibition results at values smaller than $500 \mathrm{~J} \mathrm{~cm}^{-2} \mathrm{day}^{-1}$. The values at a depth of $2.0 \mathrm{~m}$ in the bags, computed from the light values and the secchi-disc readings, according to the formulas given by Parsons \& Takahashi (1973) and Cadée \& Hegeman (1974), are almost every day below this limit. If the growth rate of the phytoplankton varies with depth, and biomass and other physico-chemical parameters do not, this indicates that the water volume in the bags is well mixed. This mixing is probably caused by the small differences in temperature observed in the bags.

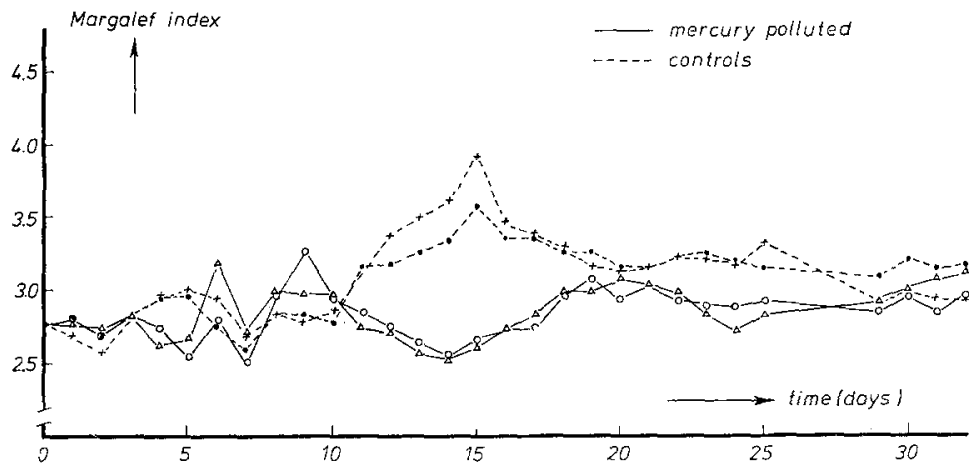

Fig. 5: Margalef index in different bags. Average from 0.5 and $2.0 \mathrm{~m}$

Figure 5 shows the value of the Margalef pigment index at different times of the experiment. No significant difference $(p<0.05)$ was found between the measurements at depths of 0.5 and $2.0 \mathrm{~m}$. Therefore, the average value of these two measurements is presented. The same pattern is found as in earlier experiments: low values at chlorophyll maxima, high values at chlorophyll minima. Carreto \& Catoggio (1976) obtained the same results working with cultures of Phaeodactylum tricornutum. They reported that the index describes in a simple way the variations in pigment proportions, increasing in value as the proportion of phytosynthetically active pigments (like chlorophyll $a$ and $c$ ) decreases. An interesting point is that, for a long period, values in the controls remain higher than in the polluted bags. This indicates that, apart from the physiological state, another factor plays a role in determining the value of the index. Probably the species structure (qualitatively, not quantitatively) is important.

The development of the concentrations of the various nutrients (averaged for two depths and corresponding bags) is given in Figure 6. It shows the same pattern as in earlier experiments. The first phytoplankton peak consumes nutrients till some nutrient reaches growth-rate limiting values. This time, this role seems to be taken by the nitrogen-containing compounds (McIsaac \& Dugdale, 1968; Eppley et al., 1969; Eppley \& Thomas, 1969; Kuiper, in prep.). After the first phytoplankton peak, nurrient concentrations stay low.

The development of the phytoplankton in separate bags shows similar patterns under identical environmental conditions; this confirms earlier results (Kuiper, in prep.) and is in agreement with results of Takahashi et al. (1975). 

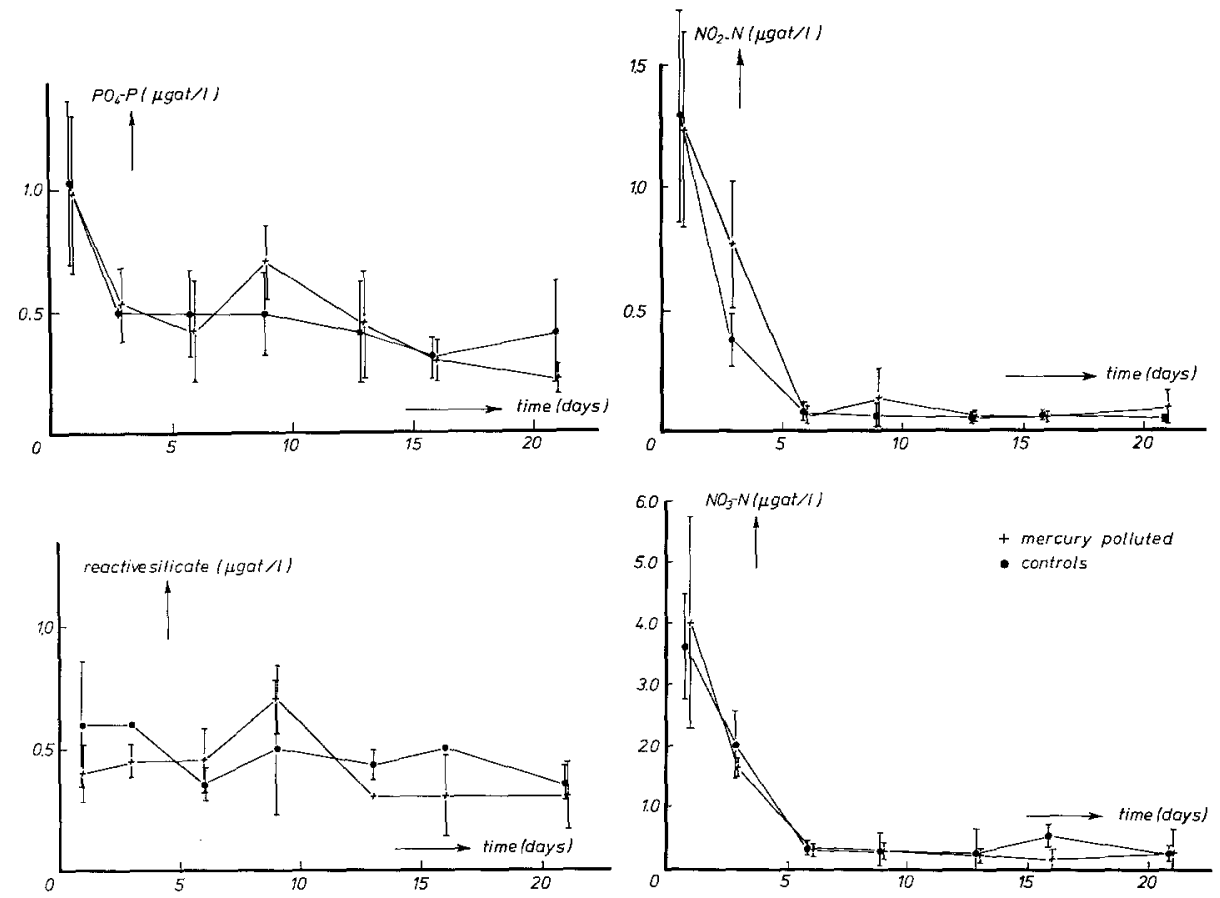

Fig. 6: Concentration of nutrients in the polluted bags and the controls. Average of two depths and replicate bags. Vertical bars indicate \pm 1 standard deviation

\section{Development of zooplankton}

Apart from the calanoid copepods Temora longicornis, Acartia clausi, Centropages hamatus and Paracalanus parvus (the latter one only in small numbers), also a harpacticid copepod, Euterpina acutifrons, develops in the bags (no clear distinction could be made between copepodites and adults of E. acutifrons). Larvae of Spio sp. sometimes formed part of the zooplankton-biomass, which cannot be ignored. Counts of these larvae showed a much higher s. $d$. than could be expected, which is probably caused by the fact that these larvae are sometimes concentrated near the bottom, so that sampling was not adequate. Further the larvae of bivalves, periwinkles and nauplii of barnacles were found in small numbers, as well as a few Podon sp.

The development of $C$. bamatus, on which the influence of the addition of the mercury was most clear, is shown in Figure 7.

In the controls and in the polluted bags, the numbers of organisms generally increased sharply. A development of the different growth stages was seen for most species. Table 2 gives the results of the analysis of the differences in population densities between the polluted bags and the controls. The densities of $T$. longicornis and C. hamatus are significantly lower in the polluted bags than in the controls; as from 
the 11 th day of the experiment, the density of E. acutifrons is significantly higher than in the controls. To investigate whether these differences in density are caused by either increased mortality or a lower growth rate, the latter rates were estimated using the model of Fransz (1976). A sex ratio of 1.0 was assumed, and in the event of possible

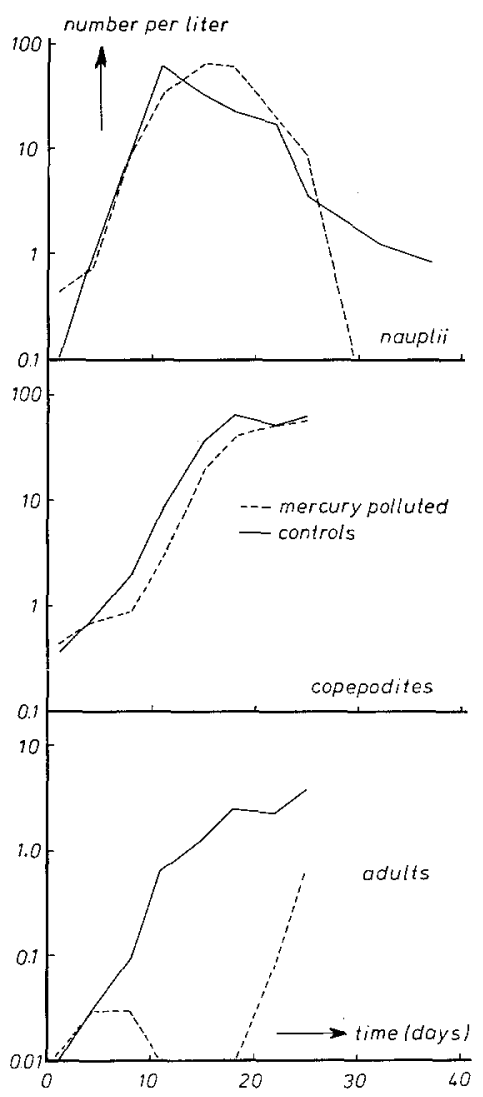

Fig. 7: Development of Centropages hamatus. Average from replicate bags (number of nauplii, copepodites and adults per liter)

negative development rates, the same corrections were applied as used by Fransz (1976). Table 3 gives the relative development and mortality rates of C. hamatus together with one half of the $95 \%$ confidence interval of these estimates. The estimates are of the same order of magnitude as Fransz (1976) found in the North Sea; this indicates that the copepods in the bags develop in a natural way.

Due to the large s. $d$. of the individual counts on which the rate estimates are based, the s. d. of these rates is also very large. Differences between the development and mortality rates in different bags are never significant. However, the differences between densities of $C$. hamatus, in the polluted bags and in the controls, coincide 
Table 2

Analysis of differences between the average population density of different organisms in the polluted bags and the controls. Analysis done with the sign-test (Wijvekate 1972) + significant difference - no significant difference. $\mathrm{Hg}<\mathrm{C}$ means: in mercury-polluted bags, the population density is lower than in the controls. $\mathrm{n}=$ nauplii; $\mathrm{c}=$ copepodites; $\mathrm{a}=$ adults

\begin{tabular}{|lclll|}
\hline \multicolumn{1}{|c}{ Species } & Stages & \multicolumn{2}{c}{ Differences } & Experimental conditions \\
\hline Temora longicornis & $\mathrm{n}$ & + & $\mathrm{p}=0.02$ & $\mathrm{Hg}<\mathrm{C}$ \\
& $\mathrm{c}$ & + & $\mathrm{p}=0.05$ & $\mathrm{Hg}<\mathrm{C}$ \\
Acartia clausi & $\mathrm{a}$ & - & & \\
& $\mathrm{n}$ & - & & \\
Centropages hamatus & $\mathrm{c}$ & + & $\mathrm{p}=0.05$ & $\mathrm{Hg}<\mathrm{C}$ \\
& $\mathrm{a}$ & - & & \\
Euterpina acutifrons & $\mathrm{n}$ & - & $\mathrm{p}=0.05$ & $\mathrm{Hg}<\mathrm{C}$ \\
& $\mathrm{c}$ & + & $\mathrm{p}=0.05$ & $\mathrm{Hg}<\mathrm{C}$ \\
& $\mathrm{n}$ & - & & \\
Paracalanus parvus & $\mathrm{a}$ & + & $\mathrm{p}=0.02$ & $\mathrm{Hg}>\mathrm{C}$ (since 11th day of \\
& $\mathrm{n}$ & + & $\mathrm{p}=0.10$ & $\mathrm{Hg}<\mathrm{C}$ \\
Spio larvae & $\mathrm{c}$ & + & $\mathrm{p}=0.10$ & $\mathrm{Hg}<\mathrm{C}$ \\
Podon sp. & $\mathrm{a}$ & - & & \\
\hline
\end{tabular}

Table 3

Estimates of the relative development and mortality rate of Centropages bamatus. In brackets, one half of the $95 \%$ confidence interval is given

\begin{tabular}{|lllllll|}
\hline $\begin{array}{l}\text { Bag } \\
\text { no. }\end{array}$ & \multicolumn{4}{c}{$\begin{array}{c}\text { Relative development rate } \\
\text { nauplii }\end{array}$} & copepodites & Relative mortality rate \\
& nauplii & copepodites & adults \\
\hline 1 & mercury-contaminated & $0.16(0.27)$ & $0.00(0.00)$ & $-0.05(0.31)$ & $0.14(0.30)$ & $0.30(0.51)$ \\
2 & control & $0.20(0.14)$ & $0.02(0.03)$ & $-0.04(0.41)$ & $0.06(0.10)$ & $0.40(0.84)$ \\
3 & control & $0.19(0.22)$ & $0.02(0.04)$ & $-0.13(0.30)$ & $0.04(0.14)$ & $0.51(0.96)$ \\
4 & mercury-contaminated & $0.12(0.06)$ & $0.00(0.00)$ & $-0.03(0.15)$ & $0.05(0.06)$ & $0.25(0.57)$ \\
\hline
\end{tabular}

with lower development rates of nauplii and copepodites in the polluted bags. Accordingly, the added mercury probably inhibited the growth rate but did not raise the mortality of C. bamatus.

Apart from the large s. $d$. of individual counts, the fact that mercury influences the zooplankton during a relatively short time only, may explain why the effects of added mercury are not more pronounced. If, for example, a small lag phase occurs in the growth of a copepod, which seems the case for C. hamatus and T. longicornis, then computation of development and mortality rates using all samples tends to hide the effect. 


\section{Development of decomposers}

The ATP measurements could not be used to evaluate the development of decomposers-biomass, which was foreseen by Jassby (1975) on theoretical grounds. However, the fact that the first phytoplankton peak, which in its growth depletes the nutrients, is followed by a second and a third, during which nutrient concentrations do not decrease considerably, indicates that, in the bags, mineralization occurs.

The second phytoplankton peak in the polluted bags is delayed four days. This lag phase is probably not caused by the fact that the phytoplankton cells need time to transform the mercuric chloride into a chemically less harmful compound (Ben Bassat et al., 1972). Concentrations of mercury in the waterphase are very low and, already on the 5th day, there was phytoplankton growth in the polluted bags. Probably the lag phase in the phytoplankton is caused by a lag phase in the growth of the decomposers, i. e. by a reduced rate of mineralization. Inhibition of bacterial growth requires mercury concentrations in the ppm range (Greeson, 1970); these concentrations were found of the experiment in the sediment of the polluted bags.

\section{"Fate" of added mercury}

The decrease of mercury concentrations in the waterphase of the treated bags is given in Table 1, while Table 4 gives the results of mercury concentration measurements in the sediment of the bags, collected at the end of the experiment (collection of sediment in Bag 3 failed).

Table 4

Concentrations of mercury and methylmercury in sediments of treated bags and controls at the end of the experiment

\begin{tabular}{|c|c|c|c|c|}
\hline $\begin{array}{l}\text { Bag } \\
\text { no. }\end{array}$ & & $\begin{array}{l}\text { Total Hg in } \\
\text { sediment (mg) }\end{array}$ & $\begin{array}{l}\text { Concentration } \\
\mathrm{Hg} \text { (ppm based } \\
\text { on wet weight) }\end{array}$ & $\begin{array}{l}\text { Concentration of methyl } \\
\text { Hg (ppb based on wet } \\
\text { weight); (s.d. 15\%) }\end{array}$ \\
\hline 1 & mercu & 0.19 & 5.4 & 2.3 \\
\hline & mercury-contaminated & 1.10 & 24.5 & 13.7 \\
\hline 2 & control & 0.003 & 0.06 & $<0.5$ \\
\hline
\end{tabular}

During the experiment, the mercury concentrated in the sediment to the ppm level. However, most of the added mercury ( $7 \mathrm{mg}$ to each bag) could not be recovered. On the walls of the bags about $40 \mu \mathrm{g}$ had adsorbed. If we assume that, till the end of the experiment, the mercury concentration in the waterphase remained $0.3 \mathrm{ppb}-$ which is not very likely (see Smith et al., 1971) - in each bag $0.4 \mathrm{mg}$ remained in the waterphase. In the sediment, $0.19 \mathrm{mg}$ and $1.10 \mathrm{mg}$, respectively, were recovered. This means that $6.4 \mathrm{mg}$ from Bag 1 and $5.5 \mathrm{mg}$ from Bag 4 are not accounted for.

A possible explanation may be the methylation of mercury in the sediment. Measurable amounts of methylmercury were found in the $\mathrm{Hg}$-contaminated bags (Table 4), and the control showed no detectable amounts of this substance. It must be 
assumed that methylmercury was formed as a result of metabolical processes. As dimethylmercury is highly volatile, it is feasible that the mercury disappeared in the atmosphere via this derivate.

Another explanation for the loss of mercury from the bags may be volatilization of the added mercury, this being the transformation into metallic mercury by bacteria (Kushner, 1974; Schottel et al., 1974).

\section{CONCLUSIONS}

A. single dose of $5 \mathrm{ppb}$ mercuric chloride added to a North Sea coastal plankton community, enclosed by a plastic bag, resulted in: (a) disappearance of the mercury from the waterphase within five days, caused by adsorption on particles that had settled on the bottom of the bags; (b) a reduced phytoplankton growth rate, as long as mercury concentrations were higher than $1.5 \mathrm{ppb}$; (c) a delay in the beginning of the second phytoplankton bloom, probably due to a lag phase in the mineralization of organic matter in the sediment; (d) a change in the community structure of the phytoplankton of the second bloom; (e) lower population densities of two copepod species, probably caused by a reciuced growth rate in the period following the mercury addition; ( $f$ ) methylation of the added mercury in the sediment.

The "plastic-bag method" seems to be a suitable tool in toxicological research.

Acknowledgements. Thanks are due to my colleagues De Kock, Hoornsman, Roele, Schrieken, Van den Eikhoff and Van het Groenewoud; they assisted in carrying out the various analyses and in evaluating the results. Acknowledgement is also due to Dr Hueck, Head of the Centraal Laboratorium's Department of Biology, for comments. The assistance of research workers of the Departments of Biology, Physics and Analytical Chemistry is greatly appreciated. I also like to thank Drs. Cadee, De Vries, Fransz, Gieskes, Hegeman and Leeuwis of the Netherlands Institute for Sea Research for their help and advice on the various aspects related to the work reported here. Finally, I would like to thank the authorities of the Royal Netherlands Navy for their kind cooperation in supplying experimental facilities. This work has been carried out under Contract No. 110-75-1 ENV N of the E. C. Environmental Research Programme.

\section{LITERATURE CITED}

Anderson, G. C. \& Zeutschel, R. P., 1970. Release of dissolved organic matter by marine phytoplankton in coastal and off-shore areas of the N.E. Pacific Ocean. Limnol. Oceanogr. 15, 402-407.

Ben-Bassat, D., Shelef, G., Gruner, N. \& Shuval, H. J., 1972. Growth of Chlamydomonas in a medium containing mercury. Nature, Lond. 240, 43-44.

Bringmann, G. \& Kuhn, R., 1959. The toxic effects of waste water on aquatic bacteria, algae and small crustaceans. Gesundheitsingenieur 80, 115.

Brockmann, U. H., Eberlein, K., Junge, H. D., Trageser, H. \& Trahms, K. J., 1974. Einfache Folientanks zur Planktonuntersuchung in situ. Mar. Biol. 24, 163-166.

Carreto, J. I. \& Catoggio, J. A., 1976. Variations in pigment contents of the diatom Phaeodactylum tricornutum during growth. Mar. Biol. 36, 105-112. 
Cadée, G. C. \& Hegeman, J., 1974. Primary production of the benthic microflora living on tidal flats in the Dutch Wadden Sea. Neth. J. Sea Res. 8, 260-291.

Clendenning, K. A., 1958. Laboratory investigations. Effects of discharging wastes on kelp 1957-58. A. Rep. Inst. mar. Res. Univ. Calif. 58-11, 29-35.

Derenbach, J. B. \& Le B. Williams, P. J., 1974. Autotrophic and bacterial production: fractionation of plankton populations by differential filtration of samples from the English Channel. Mar. Biol. 25, 263-269.

Eppley, R. W. \& Thomas, W. H., 1969. Comparison of half-saturation constants for growth and nitrate uptake of marine phytoplankton. J. Phycol. 5, 375-379.

Eppley, R. W., Rogers, J. N. \& McCarthy, J. J., 1969. Half-saturation constants for uptake of nitrate and ammonium by marine phytoplankton. Limnol. Oceanogr. 14, 912-920.

Fisher, N. S. \& Wurster, C. F., 1974. Impact of pollutants on plankton communities. Environm. Conservation 1, 189-190.

Fonds, A. W., 1971. Kwik in de Nederlandse oppervlakte-wateren. TNO-Nieuws 26, 375-377.

Fransz, H. G., 1976. The spring development of calanoid copepod populations in the Dutch coastal waters as related to primary production. In: Proceedings of the 10th European Symposium on Marine Biology. Ed. by G. Persoone \& E. Jaspers. University Press, Wetteren, 2, 247-269.

Goldman, C. R., 1962. A method of studying nutrient limiting factors in situ in water columns isolated by polyethylene film. Limnol. Oceanogr. 7, 99-101.

Greeson, P. E., 1970. Biological factors in the chemistry of mercury. Geol. Surv. Water Supply Paper 173, 32-34.

Holm-Hansen, O., 1969. Determination of microbial biomass in ocean profiles. Limnol. Oceanogr. 14, 740-747.

Horstmann, U., 1972. Ober den Einfluß von häuslichem Abwasser auf das Plankton in der Kieler Bucht. Kieler Meeresforsch. 28, 17-198.

Houpt, P. M. \& Compaan, H., 1972. Une nouvelle méthode spectrographique (emission) pour l'identification de traces de matières organiques contenant des halogènes et du mercure dans les fractions obtenus par chromatographie en phase gazeuse. Analusis 1, 27-33.

Jassby, A. D., 1975. An evaluation of ATP estimations of bacterial biomass in the presence of phytoplankton. Limnol. Oceanogr. 20, 646-648.

Kečkeš, S. \& Miettinen, J. K., 1972. Mercury as a marine pollutant. In: Marine pollution and sea life. Ed. by M. Ruivo. Fishing News Books, London, 276-289.

Kersting, K., 1975. The use of microsystems for the evaluation of the effect of toxicants. Hydrobiol. Bull. 9, 102-108.

Kushner, D. J., 1974. Microbial dealings with heavy metals. In: Proceedings of the International Conference on Transport of persistent chemicals in aquatic ecosystems. Eds: A. S. W. de Freitas, D. J. Kushner, S. U. Qadri. Nat. Research Council of Canada, 2, 59-63.

Lacaze, J. C., 1974. Ecotoxicology of crude oils and the use of experimental marine ecosystems. Mar. Pollut. Bull. 5, 153-156.

Lund, J. W. G., Kipling, C. \& Le Cren, E. D., 1958. The inverted microscope method of estimating algal numbers and the statistical basis of estimations by counting. Hydrobiologia 11, 143-170.

McIsaac, J. J. \& Dugdale, R. C., 1969. The kinetics of nitrate and ammonia uptake by natural populations of marine phytoplankton. Deep Sea Res. 16, 45-57.

Margalef, R., 1965. Ecological correlations and the relationship between primary productivity and community structure. Mem. Ist. Ital. Idrobiol. 18, 355-364.

Nuzzi, R., 1972. Toxicity of mercury to phytoplankton. Nature, Lond. 237, 38-39.

Parsons, T. R., 1974. Controlled ecosystem pollution experiment (CEPEX). Environm. Conservation $1,224$.

- \& Takahashi, M., 1973. Biological oceanographic processes. Pergamon Press, Oxford, $186 \mathrm{pp}$.

Pugh, P. R., 1973. An evaluation of liquid scintillation counting techniques for use in aquatic primary production studies. Limnol. Oceanogr. 18, 310-319. 
Ringelberg, J., 1973. Parameter-dependent (temperature) tolerance levels and the influence of the complexity of the biological system. Hydrobiol. Bull. 7, 106-114.

Schelske, C. L. \& Stoermer, E. F., 1971. Eutrophication, silica depletion and predicted changes in algal quality in Lake Michigan. Science, N.Y. 173 (3995), 423-424.

- - 1972. Phosphorus, silica and eutrophication of Lake Michigan. In: Nutrients and eutrophication. Ed. by G. E. Likens. Am. Soc. Limnol. Oceanogr., Lawrence, Kan., 157-170. (Spec. Symp. Vol. 1.)

Schottel, J., Mandal, A., Toth, K., Clark, D. \& Silver, S., 1974. Mercury and mercurial resistance determined by plasmids in Escherichia coli and Pseudomonas aeruginosa. In: Proceedings of the International Conference on Transport of persistent chemicals by aquatic ecosystems. Eds: A. S. W. de Freitas, D. J. Kushner, S. U. Qadri. Nat. Research Council of Canada, 2, 65-71.

Smith, J. D., Nicholson, R. A. \& Moore, P. J., 1971. Mercury in the water of the tidal Thames. Nature, Lond. 232, 393-394.

Steemann-Nielsen, E., 1952. The use of radioactive carbon $\left(\mathrm{C}^{14}\right)$ for measuring organic production in the sea. J. Cons. Perm. int. Explor. Mer. 18, 117-140.

Strickland, J. D. H. \& Terhune, L. D. B., 1961. The study of in situ marine photosynthesis using a large plastic bag. Limnol. Oceanogr. 6, 93-96.

- \& Parsons, T. R., 1968. A practical handbook of sea-water analysis. Bull. Fish. Res. Bd Can. 167, 1-311.

Takahashi, M., Thomas, W. H., Seibert, D. L. R., Beers, J., Koeller, P. \& Parsons, T. R., 1975. The replication of biological events in enclosed water columns. Arch. Hydrobiol. 76, 5-23.

Tjioe, P. S., de Goeij, J. J. M. \& Houtman, J. P. W., 1973. Automated chemical separations in routine activation analysis. J. radioanalyt. Chem. 16, 153-164.

Tompkins, T. \& Blinn, D. W., 1976. The effect of mercury on the growth rate of Fragilaria crotonensis Kitton and Asterionella formosa Hass. Hydrobiologia 49, 111-116.

Utermöhl, H., 1958. Zur Vervollkommnung der quantitativen Phytoplankton-Methodik. Mitt. int. Verein. Limnol. 9, 1-38.

Vollenweider, R. A. (Ed.), 1969. A manual on methods for measuring primary production in aquatic environments. Blackwell, Oxford, 225 pp.

Wijvekate, M. L., 1972. Verklarende statistiek. Het Spectrum, Utrecht, 251 pp.

Author's address: J. Kuiper

Centraal Laboratorium TNO

P.O.B. 57

Den Helder

The Netherlands 